\title{
Future Forest Management Trends In Sweden ${ }^{1}$
}

Ove Andréason

Chief Forester

Stora Kopparberg, Sweden

\begin{abstract}
The structure and production of Swedish forests are described. It is pointed out that an imbalance in age classes will result in a serious decline in allowable cut unless growth is increased and utilization is improved. Interesting measures that are being adopted to maintain annual production at the normal level are described and discussed.
\end{abstract}

\section{Résumé}

La structure et le rendement des forêts suédoises sont décrits. On signale qu'il existe un manque d'équilibre des classes d'âge qui mènera à un déclin sérieux dans la possibilité à moins que la croissance est augmentée et l'utilization améliorée. Quelques moyens, un peu extraordinaires, qu'on adopte pour soutenir la possibilité à un niveau normal sont décrits et discutés.

\section{Introduction}

Sweden is one of the northernmost countries of Europe. The 60th parallel crosses the country just north of Stockholm, the capital, and the arctic circle crosses the northern part of the country. The total land area is $450,000 \mathrm{~km}^{2}$, of which $51 \%$ or 23 million ha are productive forest land. Of this area $25 \%$ belongs to the Crown and Church, $25 \%$ to companies, and $50 \%$ to private owners, mostly farmers. Sixty-nine per cent of the private forests consist of woodlots smaller than 100 ha. Of the company forests, $85 \%$ belong to companies with holdings larger than 100,000 ha.

Scots pine (Pinus sylvestris L.) and Norway spruce (Picea excelsa) Karst) are the two main coniferous species (Fig. 1). The main species of hardwoods are birch (Betula verrucosa Ehrh. and Betula pubescens Ehrh.) and in southern Sweden, a few hardwood species are to be found.

The age class distribution of the forests is uneven (Fig. 2). There is an excess of old, and a shortage of young and middle-aged forests. These facts influence the stand treatment mainly in the following three ways: a) the mature stands with best conditions are held over; b) the development of young stands is enhanced to the utmost; and c) a build-up of large volume in the middle-aged stands is encouraged to compensate for the lack of acreage.

1The Burgess-Lane Memorial Lecture given at the Faculty of Forestry, the University of British Columbia, on November 17, 1976.
In 1923 the National Forest Survey commenced with the aim of producing information that could be used in the formation of national and regional policies concerning forestry and forest industry. This survey allows us to follow the development of the forests. The development of the growing stock of course is of great interest (Fig. 3). At the first survey period $1923 / 29$, the growing stock was 1,740 million $\mathrm{m}^{3}$. At the last period $1968 / 72$ the growing stock was $2,290 \mathrm{~m}^{3}$, i.e., somewhat lower than the previous period.

The annual growth is also of great importance (Fig. 4). The growth changed in the same way as total volume from 56 million $\mathrm{m}^{3}$ in $1923 / 29$ to 76 million in $1964 / 68$ and to 70 million in $1968 / 72$. The observations of the development of growing stock and annual growth indicate that annual cut balances annual growth and, therefore, growth must be increased or other measures must be taken if the forest industry is to expand.

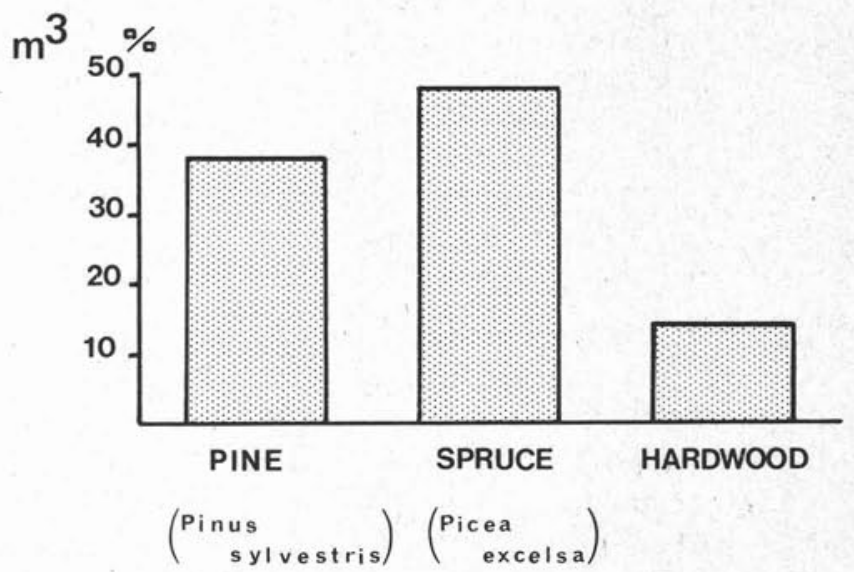

Fig. 1. Growing stock distribution.

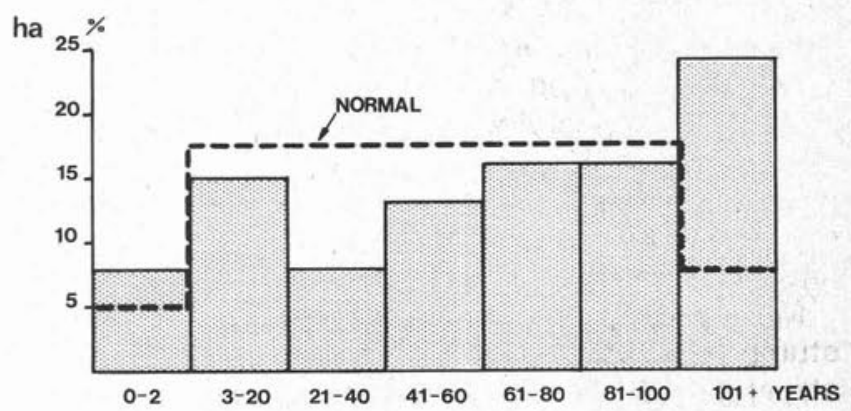

Fig. 2. Age class distribution of forests. 


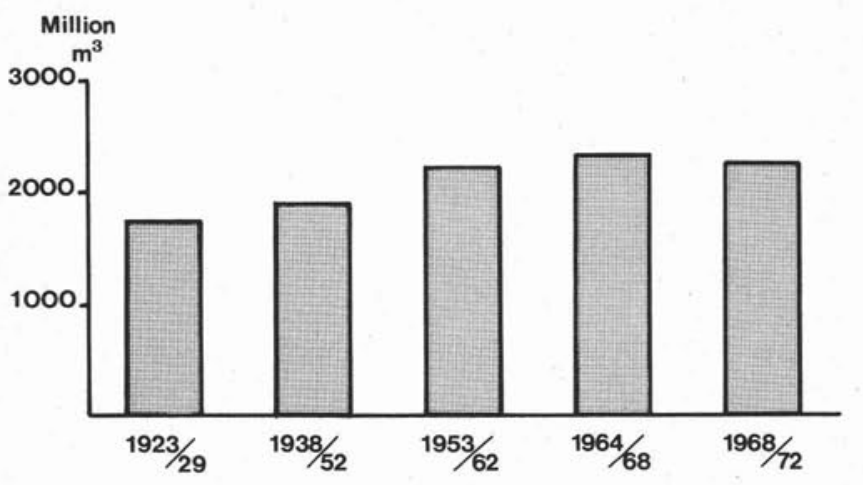

Fig. 3. The change of growing stock from $1923 / 29$ to $1968 /$ 72.

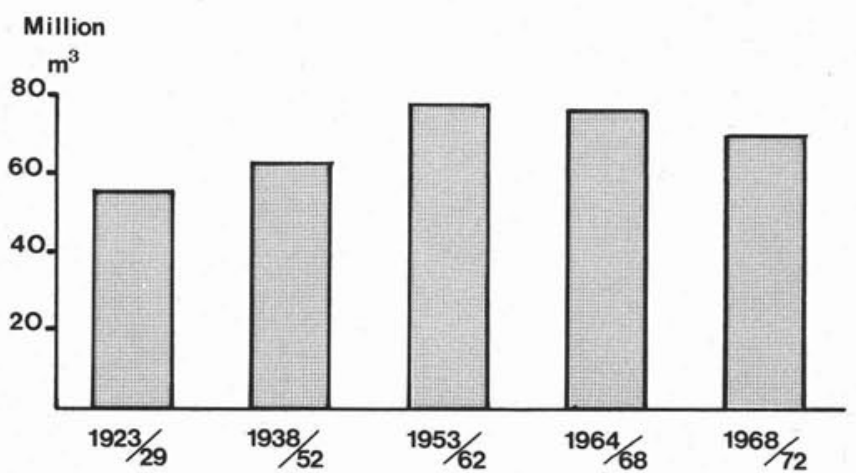

Fig. 4. The change of annual growth from $1923 / 29$ to 1968/ 72.

\section{Better Utilization of the Fibre Material}

For economic and technical reasons small trees and damaged parts of the trees have not been used before at the final cutting. Neither have trees killed by insects or fungi been used. Minimum permissible top diameter of the pulpwood has been high and considerable volumes of wood have been left in the forest. Today all parties are very interested in using these quantities and now 2-3 million $\mathrm{m}^{3}$ /year come from wood which was earlier left in the forest. It should be possible to double this quantity within the forseeable future.

The conventional harvesting method utilizes only the thicker part of the stem which represents 60 $65 \%$ of the total biomass of the tree. The remaining part consists of branches and needles (15$20 \%)$, and stumps with roots $(10-15 \%)$.

During 1974 a national project was started in Sweden to study the possibilities of using the biomass of trees somewhat better. Attempts have been made to assemble logging waste and use it in pulp production. The results show that the different fibre structure of the branches and needles makes the logging waste unsuitable for this purpose. From the biological point of view objections could also be raised against taking this material away from the forest since the needles and thinner branches contain considerable quantities of nutrients.

More promising results have been achieved with stump harvesting. There is little difference in the structure of the wood in this part of tree compared with stemwood. The ingrown stones and soil

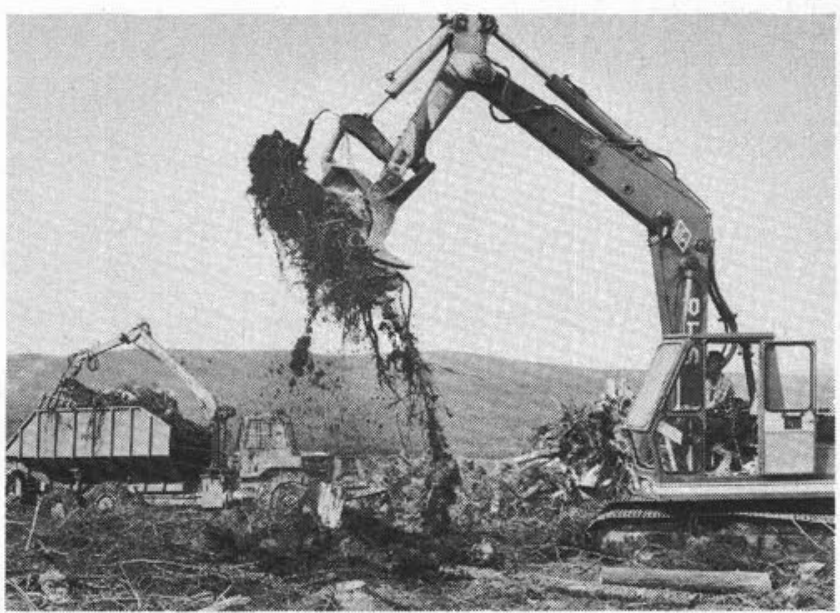

Fig. 5. Pallari Stumpharvester in operation.

particles on the stump are the great problem. A special method has been developed to remove these from the chips and we are now building the first factory for production of chips from stumpwood and root-wood. The technique to take up stumps is so far not very efficient but extensive development work is in full progress and several methods have already been tested (Fig. 5).

The costs at the factory for stump-wood are already at an acceptable level with the present technique. In Falun at Stora Kopparberg, where I am working, we believe that within two to three years about $15 \%$ of the wood from our forests will come from stump harvesting. I believe that this method will be of great importance for the wood supply in the future in Sweden since five to six million $\mathrm{m}^{3}$ (solid volume) of stumpwood could be harvested per year. To this could be added several positive effects as far as reforestation is concerned:

insect damage by Hylobius abietis will be reduced:

soil preparation will be improved; and

it will be easier to mechanize planting.

A reduction of insects will probably make it possible to plant almost immediately after clearcutting. Currently we have to wait two to three years after clear-cutting and this allows the competing grass and brush to establish themselves. Improved soil preparation should improve survival of the plants and increase their growth during the first important years. Improved possibilities to mechanize the planting are very significant. This reduced labour demand could reduce costs which is most important since they have risen alarmingly in recent years.

\section{Steps to Increase the Growth}

\section{Fertilization}

Forest fertilization on mineral soil was implemented in Sweden in 1964. The start was based on experiments made during a very long time. The first trial was made in 1907 and activities were intensified during the period 1950 to 1960 . At the 
beginning of large scale practical application of fertilizers it was quite obvious that the addition of nitrogen could increase the growth of the trees on the usual Swedish forest types.

At the beginning urea was used with $46 \%$ nitrogen content. Today we use almost all ammonium nitrate with a content of $34 \%$ of nitrogen. Ammonium nitrate gives a greater effect than urea and its efficiency is less dependent on the weather. It now appears that only ammonium nitrate will be used in the future. The amount of nitrogen has been doubled since 1964 and currently 140 $\mathrm{kg} / \mathrm{ha}$ is applied. There is no tendency to change this amount.

The effect of fertilization usually lasts six to eight years. The smaller forest owners usually fertilize the stands six to eight years before the final cutting. The forest owners with larger holdings generally start fertilization earlier with repetitions every sixth to eighth year. A great advantage with fertilization six to eight years before the final cut is that the increased increment is utilized within a relatively short time. The effect of earlier fertilization could be utilized considerably later but has, however, the great advantage that it will contribute to the build-up of growing stocks within the middle-aged stands where we today have a great shortage.

From the start the fertilization increased rapidly to 100,000 ha and came to a stagnation for some years at that level (Fig. 6).

During recent years there has been a remarkable increase and in 1974169,000 ha were fertilized. At this level annual growth in the forests increases by 2 million $\mathrm{m}^{3}$. The potential increase is estimated to be about 10 million $\mathrm{m}^{3}$, but since the private forests consist of small woodlots, fertilization may not reach that magnitude. In my opinion fertilization will produce an annual increment increase of 4-6 million $\mathrm{m}^{3}$ which corresponds to 5$10 \%$ of the present growth of the country.

\section{Drainage}

A considerable part of the Swedish forest land has a reduced increment because it is too wet. About 1.5 million ha of this land could be drained to increase the increment. According to an investigation 2-2.5 million ha of non-productive peat land could be made productive by drainage and fertilization with phosphorus and potassium. When estimating this area both environmental aspects and suitable form and location of the land have been taken into consideration. Growth on ditched and fertilized peat land would be the same as on surrounding mineral soil. The total production increased by drainage, plus fertilization when needed, has been estimated to be 10 million $\mathrm{m}^{3} /$ year. The larger forest owners have increased drainage programs considerably during the last years, but I believe that it will take a long time before the combination of drainage and fertilization will reach this expectation in Sweden.

\section{Stand Establishment}

Artificial regeneration - mostly planting -

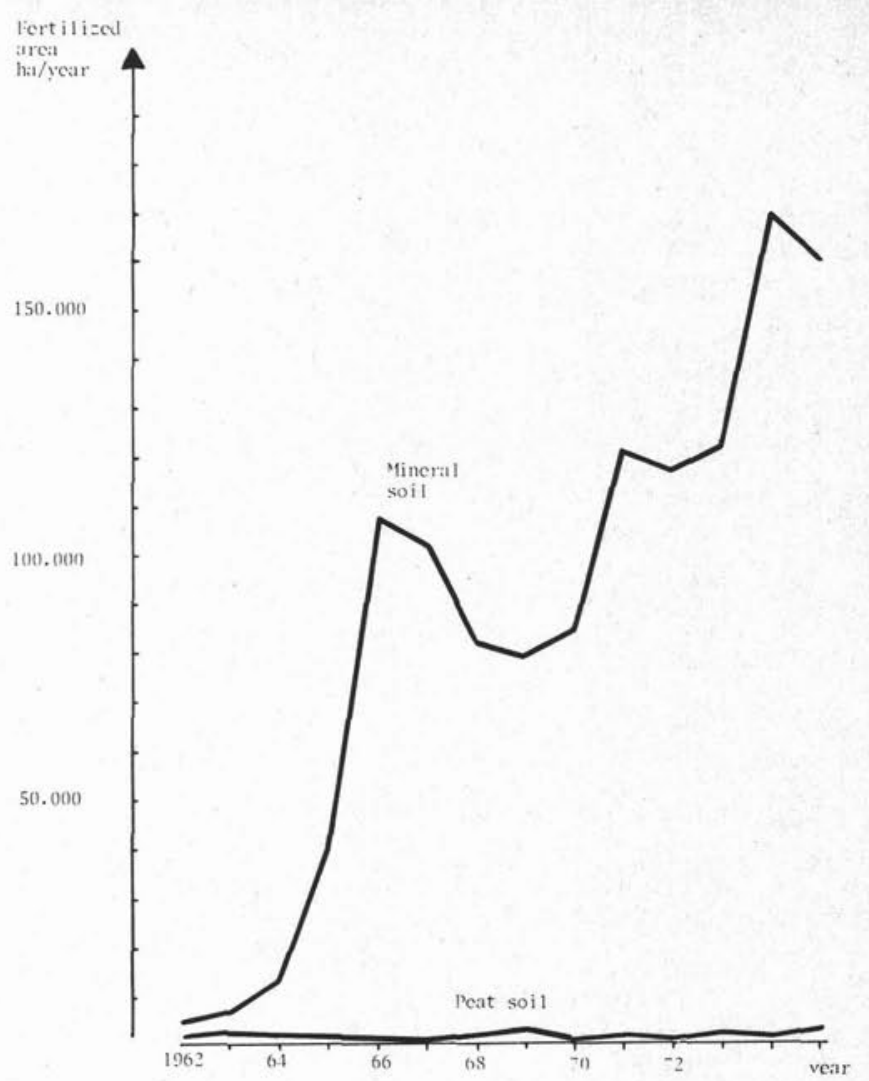

Fig. 6. The annual fertilized area on mineral and on peat soils in Sweden.

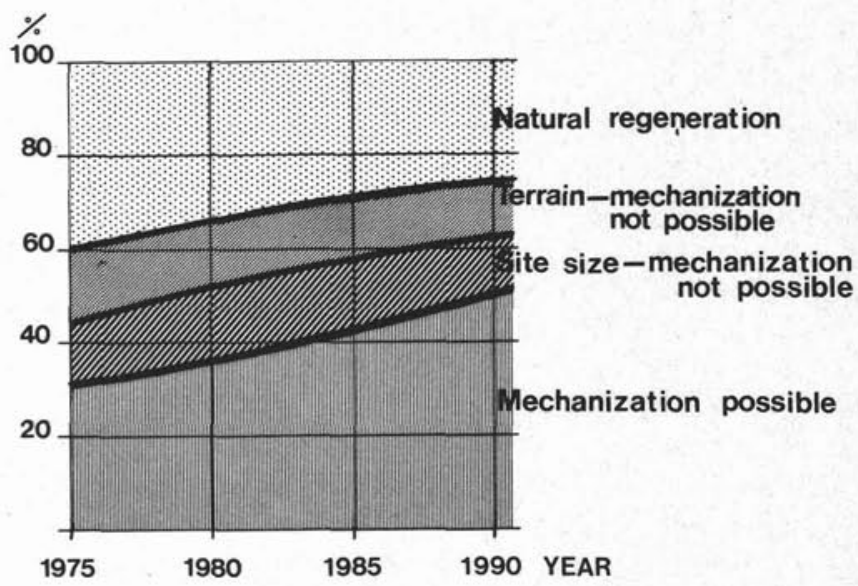

Fig. 7. Distribution of natural and artificial regeneration areas from 1975 to 1990 .

amounted to $60 \%$ of the harvested area in 1975 and the remaining $40 \%$ was regenerated naturally using seed trees. It is estimated that natural regeneration will be reduced to $25 \%$ by 1980 and that artificial regeneration will be increased to $75 \%$ (Fig. 7).

The Logging Research Foundation in Sweden has been studying the possibilities of mechanizing the increasing artificial regeneration work. Regarding the total reforestation area they have found that:

1. On $30 \%$ of the area it is possible to use mechanized methods and that the share can be increased to $50 \%$ in 1990 ,

2. on $15 \%$ of the area it is impossible to mechanize 
the work because areas are too small, and

3 . On another $15 \%$ of the area mechanized methods can not be used because of terrain difficulties.

The possibility to mechanize artificial regeneration will increase from $50 \%$ in 1975 to $65 \%$ in 1990 (Fig. 8). This means that manual systems will still be used on $35 \%$ of the area in 1990. The Research Foundation has also made a prognosis regarding how soon mechanized systems will be introduced. The first planting machines will be put into use in the next two years. About 1985 the machines will be used on $35 \%$ and about half the area in 1990.

The types of planting stock change rapidly. In 1970 almost only bare-rooted plants were used (Table 1), while in 1975 the proportions were $64 \%$ bare-rooted and $36 \%$ rooted in containers.

Table 1. Distribution of types of seedlings from 1970 to 1985.

\begin{tabular}{|c|c|c|c|c|}
\hline \multirow[b]{2}{*}{ Type of Planting Stock } & 1970 & 1975 & 1980 & 1985 \\
\hline & \multicolumn{4}{|c|}{ per cent } \\
\hline Bare-rooted Plants. . ...... & 97 & 64 & 35 & 28 \\
\hline $\begin{array}{l}\text { Rooted Plants in } \\
\text { Containers...... }\end{array}$ & 3 & 36 & 65 & 72 \\
\hline
\end{tabular}

According to the forecast the share of rooted seedlings will increase and in 1985 represent more than $70 \%$ of all plants. Paper pots has so far been the most widely used container and then the multipot system. Both types have certain disadvantages and we are therefore interested in getting a new type of container.

Rooted cuttings have been used in tree breeding work earlier. We are now trying to develop the techniques of producing cuttings for larger scale reforestation. The costs, however, will most certainly become very high and therefore the cuttings are intended to be used only on the best forest sites.

\section{Species}

In reforestation work the two main species, Norway spruce and Scots pine, are used - spruce on better sites and pine on the poorer. Today $50 \%$ of the pine seed comes from seed orchards, and in 10 years it will be $100 \%$. The spruce seed orchards will not yield appreciable quantities for another 10 years.

Increased yield production is already evident from our earlier established Scots pine seed orchards. On the lowest site quality and class .6 $\mathrm{m}^{3} /$ ha or $38 \%$ more wood is produced from seed originating from seed orchards as compared to seed collected from natural stands (Table 2). On the best soil the difference is $1.2 \mathrm{~m}^{3}$ or $19 \%$. (The smaller percentage is because the calculation is made on a greater absolute figure.)

During recent years we have started to plant lodgepole pine from B.C. and the Yukon to a cer-

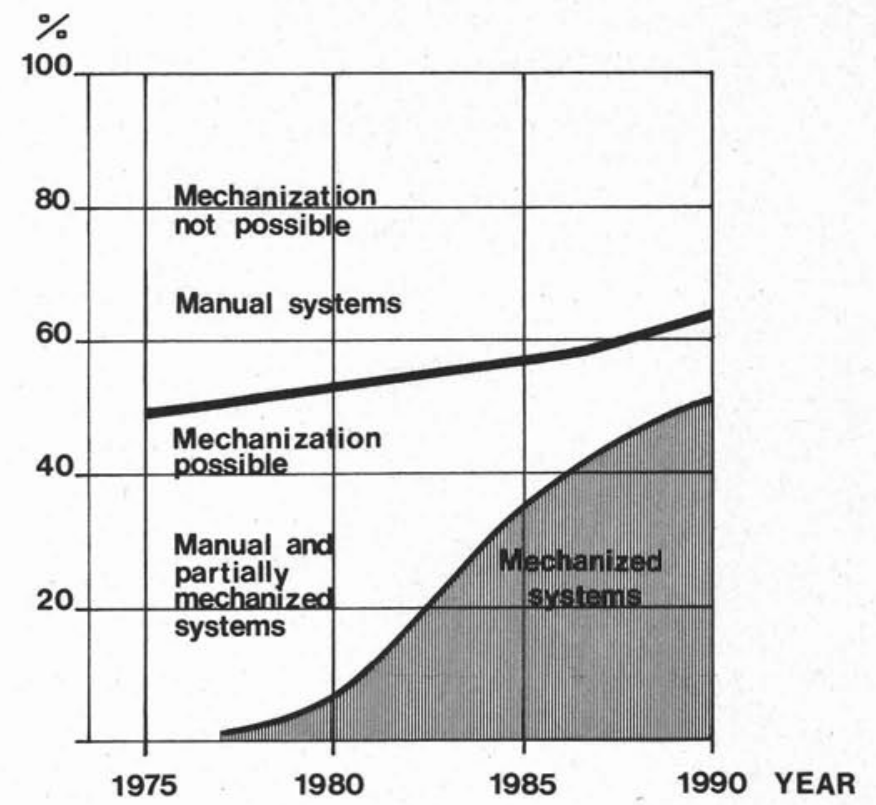

Fig. 8. Distribution of manual and mechanical regeneration areas from 1975 to 1990.

Table 2. Volume production over bark of Scots pine from from natural stands and from seed orchards.

\begin{tabular}{|c|c|c|c|c|}
\hline \multirow{2}{*}{$\begin{array}{l}\text { Site } \\
\text { Class } \\
\text { H } 100\end{array}$} & \multirow{2}{*}{$\begin{array}{c}\text { Natural } \\
\text { stands } \\
\text { Mean } \\
\text { production } \mathbf{m}^{3}\end{array}$} & \multirow{2}{*}{$\begin{array}{c}\text { Seed } \\
\text { orchards } \\
\text { Mean } \\
\text { production } \mathbf{m}^{3}\end{array}$} & \multicolumn{2}{|c|}{ Difference } \\
\hline & & & $\mathbf{m}^{3}$ & $\%$ \\
\hline $\begin{array}{l}14 \\
18 \\
22 \\
26\end{array}$ & $\begin{array}{l}1.6 \\
2.8 \\
4.4 \\
6.4\end{array}$ & $\begin{array}{l}2.2 \\
3.6 \\
5.4 \\
7.6\end{array}$ & $\begin{array}{l}+0.6 \\
+0.8 \\
+1.0 \\
+1.2\end{array}$ & $\begin{array}{l}+38 \\
+29 \\
+23 \\
+19\end{array}$ \\
\hline
\end{tabular}

Table 3. Volume production under bark of Scots pine from natural stands and lodgepole pine.

\begin{tabular}{|c|c|c|c|c|}
\hline \multirow{2}{*}{$\begin{array}{c}\text { Site } \\
\text { Class } \\
\text { H } \\
\mathbf{1 0 0}\end{array}$} & \multirow{2}{*}{$\begin{array}{c}\text { Scots pine/ } \\
\text { natural } \\
\text { stands } \\
\text { Mean } \\
\text { production } \mathbf{m}^{3}\end{array}$} & \multirow{2}{*}{$\begin{array}{c}\text { Lodgepole } \\
\text { pine } \\
\text { Mean } \\
\text { production } \mathrm{m}^{3}\end{array}$} & \multicolumn{2}{|c|}{ Difference } \\
\hline & & & $\mathbf{m}^{3}$ & $\%$ \\
\hline $\begin{array}{l}14 \\
18 \\
22 \\
26\end{array}$ & $\begin{array}{l}1.4 \\
2.3 \\
3.8 \\
5.6\end{array}$ & $\begin{array}{l}2.3 \\
3.4 \\
5.0 \\
7.0\end{array}$ & $\begin{array}{l}+0.9 \\
+1.1 \\
+1.2 \\
+1.4\end{array}$ & $\begin{array}{l}+64 \\
+48 \\
+32 \\
+25\end{array}$ \\
\hline
\end{tabular}

tain extent in Sweden. The reasons for this are results from various experiments of which the oldest are more than 40 years. Jan Remrod has just recently published results from calculations regarding the production of lodgepole pine on different site qualities and he compares it with Scots pine from natural stands (Table 3 ), and from seed orchards (Table 4). Regarding natural stands, lodgepole pine gives $0.9 \mathrm{~m}^{3}$ or $64 \%$ more on poor sites and $1.4 \mathrm{~m}^{3}$ or $25 \%$ on good sites. Compared with pine from seed orchards the superiority is much less $-0.5 \mathrm{~m}^{3}$ or $28 \%$ on land with low production and $0.3 \mathrm{~m}^{3}$ or $5 \%$ on high production land. 
Table 4. Volume production under bark of Scots pine from seed orchards and lodgepole pine.

\begin{tabular}{|c|c|c|c|c|}
\hline \multirow{2}{*}{$\begin{array}{l}\text { Site } \\
\text { Class } \\
\mathbf{1 0 0}\end{array}$} & \multirow{2}{*}{$\begin{array}{c}\text { Scots pine/ } \\
\text { seed } \\
\text { orchards } \\
\text { Mean } \\
\text { production } \mathbf{m}^{3}\end{array}$} & \multirow{2}{*}{$\begin{array}{c}\text { Lodgepole } \\
\text { pine } \\
\text { Mean } \\
\text { production } \mathbf{m}^{3}\end{array}$} & \multicolumn{2}{|c|}{ Difference } \\
\hline & & & $\mathbf{m}^{3}$ & $\%$ \\
\hline $\begin{array}{l}16 \\
20 \\
24 \\
28\end{array}$ & $\begin{array}{l}1.8 \\
3.0 \\
4.6 \\
6.7\end{array}$ & $\begin{array}{l}2.3 \\
3.4 \\
5.0 \\
7.0\end{array}$ & $\begin{array}{l}+0.5 \\
+0.4 \\
+0.4 \\
+0.3\end{array}$ & $\begin{array}{l}+28 \\
+13 \\
+9 \\
+5\end{array}$ \\
\hline
\end{tabular}

In practice this should mean that lodgepole pine will be planted on forest land with low production which is to be found at high elevations and in the northern part of the country. During 1975 lodgepole pine was planted on about $10 \%$ of the total planted area. Most certainly its use will increase.

Old provenance experiments have shown that about $20 \%$ greater growth of Norway spruce is obtained in the south of Sweden if the species is taken from eastern Europe - White Russia, Romania and Poland. Therefore, today spruce from eastern Europe is planted on approximately $10 \%$ of the planting area or the same acreage as lodgepole pine and the tendency shows an appreciable increase.

\section{Summary}

The development of Swedish forestry is, of course, due to many factors. Changes in cost and timber prices have a great effect. Of great importance also are the differences existing regarding size of land holdings for different owner categories. The large land holders can use the new methods earlier than the small landowners. My conclusions about the tendencies within Swedish forestry must be considered in this light.

The raw material will be utilized better than before. This improvement will be obtained by using more of the stemwood and by stump harvesting. Stump harvesting should expand rapidly and supply the forest industry with important quantities of new wood material. Stump harvesting will produce several positive biological effects.

Fertilization on mineral soil will increase the total growth of the Swedish forests by $5-10 \%$. Drainage of wet mineral forest soils will be intensified. The non-productive peat land represents an important production potential but it is hard to anticipate to what extent this land can be made productive by drainage and fertilization.

The proportion of natural regeneration will be reduced and the artificial will increase. The mechanization of artificial regeneration will start in a few years and will expand rapidly. The importance of rooted plants will increase in the future. It is possible that cuttings will be used on the best sites.

Today, lodgepole pine of central and northern British Columbia provenances and Norway spruce of eastern European origin are planted in about the same proportions - together about $20 \%$ of the planting area of the country. It is probable that the use of these species will increase in future to increase wood production in Sweden.

\section{Acknowledgements}

I wish to express my gratitude to British Columbia Forest Products Ltd. and the University of British Columbia for the opportunity to give this lecture. A special thanks goes to Professor Oscar Sziklai who was particularly helpful in connection with the lecture. 